University of Louisville

ThinkIR: The University of Louisville's Institutional Repository

Faculty Scholarship

$1-2013$

Rethinking critical mass in the federal appellate courts.

Laura Moyer

University of Louisville, laura.moyer@louisville.edu

Follow this and additional works at: https://ir.library.louisville.edu/faculty

Part of the American Politics Commons, Courts Commons, Gender and Sexuality Commons, and the Judges Commons

Original Publication Information

Moyer, Laura. 2013. "Rethinking Critical Mass in the Federal Appellate Courts." Journal of Women, Politics, and Policy 34(1): 49-71.

This Article is brought to you for free and open access by ThinkIR: The University of Louisville's Institutional Repository. It has been accepted for inclusion in Faculty Scholarship by an authorized administrator of ThinkIR: The University of Louisville's Institutional Repository. For more information, please contact thinkir@louisville.edu. 


\title{
Rethinking Critical Mass in the Federal Appellate Courts
}

\author{
Laura Moyer, Louisiana State University
}

Version: August 27, 2012

SUMMARY. This article draws from critical mass studies of gender in other political institutions to inform an application to the US Courts of Appeals. The results demonstrate the utility of considering court-level aspects of diversity. As mixed-sex panels become more common within a circuit, both male and female judges increasingly support plaintiffs in civil rights claims, though the magnitude of the effect is larger for women. The presence of a female chief judge is also positively associated with pro-plaintiff decisions by men and women in sex discrimination cases.

KEYWORDS: critical mass, US Courts of Appeals, federal judges, women, gender, judicial decision making 
Although white men have historically been the primary participants in the legal system as judges and attorneys, women have dramatically increased their presence in law school and the legal profession since the 1970s (Martin, Reynolds, and Keith 2002, 666). Research has highlighted the impact of diversifying the judiciary in terms of its symbolic importance for institutional legitimacy (Epstein et al. 1995), its substantive importance for particular segments of society, such as women (Allen and Wall 1993), and as a mechanism for producing better deliberation (Solimine and Wheatley 1995). The composition of the federal courts has changed substantially over the past thirty years, leading many to ask what, if any, differences in judging we can observe as a result of this transformation. Existing research about gender and judging in the federal courts has compared men and women judges' voting behavior using a variety of methodological approaches (Davis 1993; Songer, Davis and Haire 1993; Walker and Barrow 1985) and has also examined the effect of panel composition on outcomes (Boyd, Epstein, and Martin 2010; Farhang and Wawro 2004). At the US Courts of Appeals level, the results have been mixed, suggesting differences between men and women judges in only a few areas of law, such as criminal cases (Collins and Moyer 2008) and employment discrimination (Boyd, Epstein, and Martin 2010; Songer, Davis, and Haire 1993). ${ }^{1}$

Bridging the literature on gender and judging with legislative studies of critical mass, I offer a new perspective on how the composition of a court may affect outcomes. Rather than focusing only on the individual level, I argue that we must consider the institutional context of a court in shaping gendered behavior. The US Courts of Appeals provide an optimal testing ground for exploring institutional context because they rely upon rotating three-judge panels. Since each circuit differs substantially with respect to the total number of judges and the number of women, there is a great deal of variation across circuits in terms of how often judges decide 
cases on mixed-sex panels. Should we expect the behavior of female (and male) judges to be the same in courts where most cases are decided by all-male panels of judges, compared to courts where panel regularly seat men and women judges together? I investigate these questions using decisions in a broad range of civil rights cases (1982-2002), as well as a more detailed sample of employment discrimination cases filed by female plaintiffs (1995-2002), and find support for considering the institutional context.

\section{THE ROLE OF JUDGE GENDER IN THE US COURTS OF APPEALS}

Given that judges on the Courts of Appeals share the same professional training and socialization, it would be reasonable to assume that no systematic differences in decision-making behavior exist between the sexes. Recognizing this, the bulk of the literature on gender in the US Courts of Appeals has tended to focus on identifying salient conditions under which judges' behavior may be affected by gender in observable ways. A growing number of analyses have found that female judges are more likely to support the plaintiff in employment discrimination appeals (Boyd, Epstein, and Martin 2010; Crowe 1999; Farhang and Wawro 2004; Peresie 2005; Songer, Davis, and Haire 1994; but see Westergren 2004).

However, the causal mechanisms by which a judge's gender is hypothesized to affect legal outcomes have remained the subject of much debate. While some have suggested that gender operates subconsciously in shaping individuals' frameworks of moral reasoning (Gilligan 1982), others point to the role of external forces. Judges are not exempt from socialization processes that emphasize differences between men and women, and in their personal and professional lives, they have had gendered experiences that may affect how they perceive the world around them (Duerst-Lahti and Kelly 1995). For instance, a survey of judges and attorneys found that women observed more gender bias than men did, even after controlling for 
marital or parental status, age, and race (Martin, Reynolds, and Keith 2002). Yet another perspective, referred to as active or substantive representation, argues that women will act to benefit other women as a group (under particular circumstances when gender becomes "salient"). One notable difference between "subconscious" and "conscious" accounts of gendered decisionmaking is that in the first case, women judges might be expected to decide all, or a wide variety of, cases differently since they possess a different moral framework for reasoning (Gilligan 1982), while in the second case, women judges will actively choose to make decisions that benefit women (Allen and Wall 1993).

A more recent approach has been to expand the focus from female judges and to instead look at whether male judges behave differently when they are in the presence of a female colleague on a panel. Increasingly, empirical evidence supports this hypothesis in sex discrimination cases (Boyd, Epstein, and Martin 2010; Crowe 1999; Peresie 2005;) and other employment discrimination cases decided by appellate panels (Farhang and Wawro 2004).

\section{THE CAUSAL MECHANISM FOR GENDER EFFECTS}

What accounts for findings suggesting gender effects in employment discrimination cases? One possible explanation is that female judges' personal experiences have made them more sensitive to claims of others alleging discrimination. Most of the female judges on the federal bench between 1982 and 2002 attended law schools that were majority-male and gained professional experience in professions and organizations in which women were in the minority (Curran and Carson 1994). Indeed, a survey of federal judges published in 1990 found that female judges overwhelmingly listed sex discrimination as a "major concern" in the legal profession, while male judges failed to mention it at all (Martin 1990, 207). Moreover, even if a female judge happened to be trained, socialized, and employed solely in sex-balanced institutions 
prior to being appointed to the Courts of Appeals, no circuit ever approached a 60-40 split between men and women (let alone a 50-50 balance). Therefore, it is reasonable to expect that these professional experiences as a numerical minority may tend to increase a female judge's propensity to side with plaintiffs claiming discrimination. Indeed, even a sitting Supreme Court justice has alluded to this possibility. In a recent interview, Ruth Bader Ginsburg observed that the presence of female judges might change the outcomes of sex discrimination cases "because the women will relate to their own experiences" (Bazelon 2009).

The question then becomes, how does diversification of a court affect male judges? Recent evidence suggests that male judges are more likely to side with the plaintiff in employment discrimination cases when the panel includes a woman. Several explanations seem possible for this behavior. First, because of their professional experiences as a numerical minority, female judges might opt to influence their male colleagues overtly, through persuasion and advocacy on a panel. This is the conclusion drawn by Farhang and Wawro $(2004,325)$, who propose that the presence of a woman on a panel allows that judge to modify the content of the majority opinion through both deliberation and bargaining. Research in social psychology and sociology supports this interpretation; namely, that when a task is associated with women, then women are more likely to exert greater influence in mixed-sex groups then men, who tend to defer in these situations (Ridgeway and Smith-Lovin 1999).

A second possibility is that the influence might occur more indirectly; for instance, a woman's mere presence on a panel might make her male colleagues more "sensitive" to claims of discrimination by plaintiffs. Support for this interpretation is bolstered by a survey of women judges in which respondents reported that they believed their presence raised the consciousness of male colleagues (Martin 1999). Indirect influence may also be a product of small group 
dynamics on the panel, due to gender-based differences in communication and leadership styles (Coates 1988; Eagly and Johnson 1990; Smith-Lovin and Brody 1989). Other research suggests that gender differences will be greatest in groups that are involved in short or one-time encounters, and, over time, gender differences in goal-directed activities disappear (Aries 1998; Milliken and Martins 1996; Wheelan and Verdi 1992). Since judges in the Courts of Appeals sit in rotating panels focused on the task of deciding a case, this environment may be conducive to producing gender-driven behavior differences.

Gender effects may also be attributed to changes in organizational culture within a court that occur because of the composition of the judges. Chatman and Spataro (2005) find that demographically distinct individuals (in terms of race, gender, and national origin) behaved more cooperatively when their business unit emphasized collectivistic cultural values, rather than individualistic ones. Considering the strong norms of consensus and collegiality in the Courts of Appeals (Hettinger, Lindquist, and Martinek 2006) and findings about female judges' impact on male colleagues, the gender composition of the court may produce institutional norms influenced by the experiences of female judges. ${ }^{2}$

\section{“CRITICAL MASS" AND THE COMPOSITION OF POLITICAL INSTITUTIONS}

The political science literature on gender and judging in the federal appellate courts has tended to focus on individual and panel-level approaches to the exclusion of court-level analyses of gender diversity. For this reason, studies of gender composition in legislative bodies provide a number of important insights for aggregate level analyses of gender effects in courts. These studies of state and national legislatures often use the work of Kanter (1977) and Dahlreup (1988) as their point of departure. The "critical mass" argument, as described by Kanter (1977), predicts that when groups who are in the minority reach a certain proportion, they become 
individuals who are distinguished from one another and can form coalitions that affect the organization's culture. The flip side of this assertion is that when the levels of women in an organization fall below this point, women may try to downplay their differences, or they may simply have less success in accomplishing their goals because of their small numbers (Grey 2002; Saint-Germain 1989; Thomas 1994). Recent research has challenged the way in which the critical mass argument has been characterized and tested in the literature (Beckwith 2007; Childs and Krook 2008), as well as the conclusion that female lawmakers in "skewed" legislatures (where the proportion of women falls below 15 percent) cannot effectively represent women's interests (Bratton 2005).

Studies of gender composition in legislative institutions raise important questions that may be relevant for the federal appellate court context. One such question is whether some fixed proportion of women is necessary for changes in institutional outputs to be observed. Answers to this question in the legislative context have been largely dependent on measurement. Bratton (2005, 99-100) observes that variation in the type of dependent variable used tends to influence whether or not a critical mass interpretation can be supported. Indeed, some scholars have even documented a "backlash effect" as women's relative representation increases (Kathlene 1994). ${ }^{3}$

Another question raised by the literature is how to measure women's relative presence. A number of scholars have advocated moving away from using a fixed proportion (or "critical mass point") in legislative institutions, observing that there is little theoretical basis for a single "magic" number at which substantive representation, or other gender-driven effects, will always occur (Bratton 2005; Childs and Krook 2008; Dahlerup 2006). For example, Poggione (2004) has shown that opportunities to build coalitions or to engage in substantive representation for gender may be constrained or negated by institutional structures and norms both inside and 
outside the organization. However, alternatives to using a single critical mass point can run into other measurement problems. Categorical measures that identify ranges of diversity may miss out on significant effects depending on what range is specified, and they often lack adequate justification for the values associated with each range (for example, using 0-15\% as "low" diversity, as opposed to using 0-30\%). Heterogeneity indices (where diversity is measured continuously from 0 to 1) may also be problematic because they assume symmetrical effects for men and women; namely, that a group of 10 with 2 women and 8 men will behave the same as a group of 10 with 2 men and 8 women. Williams and Mean (2004, 459-463) discuss these disadvantages in detail and advocate using proportional measures with interaction terms to test whether the effect differs for men and women.

Of course, there are significant institutional differences between legislative bodies and the federal circuit courts that complicate importing findings about critical mass from one arena into another. Legislators have an electoral incentive to act to further the interests of particular constituencies, such as women voters. Appeals courts judges are appointed by the president and confirmed by the Senate and, for the most part, have been socialized in their legal training to conceptualize of their role to be an objective arbiter of justice, and not a representative of any particular group (Martin, Reynolds, and Keith 2002, 667).

There are also significant differences between the institutions in terms of decisionmaking structures and processes. The primary decision-making unit in the Courts of Appeals is a three-member panel to which judges and then cases are assigned. In larger courts (e.g., the Ninth Circuit), any two judges may not sit together on a panel more than a few times per year and may not even have chambers in the same city (or state). Additionally, because the Courts of Appeals must hear every case that is properly brought before them and for which they have jurisdiction, 
circuit judges lack the discretion to "cherry pick" cases that might, for example, highlight the salience of gender. Compared to legislators who actively engage in policymaking via bill sponsorship, voting, and committee negotiations on the content of proposed legislation, judges are reactive participants in policy making, relying on litigants to raise issues of legal and public policy. Taken together, these institutional differences emphasize the importance of avoiding a "one size fits all" approach to theorizing about gender and political institutions. Instead, scholars should tailor their expectations to the unique institutional norms and constraints that structure decision making in the institution being studied (Farhang and Wawro 2004, 304-310).

\section{THE GENDER CONTEXT OF THE COURT AND SALIENT ISSUE AREAS}

Previous Courts of Appeals research that has focused on panel, but not court-level, composition suggests that employment discrimination cases present a salient issue area for women judges, who are more likely to support female plaintiffs than male judges (Boyd, Epstein, and Martin 2010; Peresie 2005). This is consistent with a more traditional interpretation of substantive representation: women are acting to benefit other women. However, male judges' increased propensity to support female plaintiffs in sex discrimination cases when seated on mixed-sex panels (compared to all-male panels) suggests a broader effect; namely, that female judges can help improve outcomes for women in other ways (Boyd, Epstein, and Martin 2010).

When moving to a court-level conceptualization of sex composition, it is important to be open to the possibility that exposure to gender diversity within a judicial institution may have a variety of effects. The panel-level studies suggest that working in small, mixed sex groups changes the voting behavior of judges in some, but not all, kinds of cases. Therefore, when testing for the effects of frequent exposure to these mixed sex groups, it is important to test whether previous findings in the area of employment discrimination have simply been part of a 
larger phenomenon in civil rights cases more generally, or whether the employment discrimination context is distinctive. To address these questions, I model the likelihood that a judge will cast a vote in favor of a plaintiff claiming discrimination. The dependent variable is coded as a " 1 " if a judge sided cast a pro-plaintiff vote and as a " 0 "if the judge sided with the defendant (excluding cases where the outcome could not be clearly classified as either proplaintiff or pro-defendant).

\section{MEASURING SEX COMPOSITION}

A number of scholars have called for further examination of the role that organizational context plays in mediating the effects of diversity in groups (Riordan 2000; Tsui, Egan, and O'Reilly 1995). In the Courts of Appeals context, the frequency with which mixed-sex panels are constituted is a more institutionally appropriate proxy for the sex composition of a circuit than a simple proportion. On collegial courts where all members sit en banc to hear every case (such as state supreme courts), a different approach to testing the critical mass hypothesis would be warranted (Martin and Pyle 2005; McCall 2008).

One approach to measuring the sex composition of a circuit would be count the number of times that mixed-sex panels actually were constituted in each circuit. Unfortunately, this approach has several limitations. Because it would necessarily be based on only the panels observed in published opinions, an actual count would systematically omit the many instances in which men and women sit together on panels for which no published opinion is issued. Cohen (2002) and others have noted substantial differences across circuits in publication rates; during the time period examined here (1982-2002), publication rates varied tremendously across circuits and years, from as low as 8 percent to as high as 67 percent. Since there is no theoretical reason 
for expecting the effect of a mixed-sex panel, or circuit composition, to be related only to published opinions, the conceptual validity of such a measure is weak.

An approach that is both conceptually valid and not affected by issues related to circuit variation in publication rates is to use the probability that a mixed-sex panel will be constituted as a proxy for the frequency of mixed-sex panels. For every circuit, I calculated the yearly proportion of possible panels in which there could be zero, one, two, or three women on the panel at the same time, given the total numbers of men and women for each circuit-year. I include both active and senior status judges from within the circuit, the latter of which contribute to a significant amount of the circuit's work, in order to lessen caseload pressures. (Between 1982 and 2002, senior judges across all circuit participated in an average of 13 percent of cases decided on the merits.) Although it is true that senior judges must assume a lessened caseload compared to active judges, Benesh (2006) found that in the Ninth Circuit, senior judges actually wrote more than their share of majority opinions. So while the disparity in participation between active judges and senior judges means that the measure is not a perfect one, omitting samecircuit senior judges from the analysis would be more problematic, since these judges continue to be an important part of the work of the circuit (Yoon 2005) and, as men and women, likely still influence the organizational culture with their continued presence and participation. ${ }^{4}$

To illustrate how this variable was calculated, suppose a circuit has 28 judges and 6 women. First, I determine the proportion of possible panels that have three women (WWW). Because there are three spots on a panel, the first spot represents any of the 6 women and any of the 28 spots, the second represents one of the 5 remaining women out of the 27 remaining judges, and the third spot represents one of the 4 remaining women out of the 26 remaining judges. When these fractions are multiplied together $(6 / 28 \times 5 / 27 \times 4 / 26)$, we see that three- 
female panels make up $0.6 \%$ of all possible panels (i.e., they are quite rare). To determine the proportion of possible panels that could have two women and one man, there would be three permutations of panel order $(6 / 28 \times 22 / 27 \times 5 / 26)$, which equals $3.4 \%$. Because the order that one picks (WWM, WMW, MWW) simply rearranges the numbers in the numerator of the fractions without changing the final calculation, the total $(3.4 \%)$ is multiplied by three.

Therefore, the total proportion of possible panels with two women and one man is $10.1 \%$. Next, I compute the proportion of possible panels that have one woman and two men $(6 / 28 \mathrm{x} 22 / 27 \mathrm{x}$ $21 / 26=14.1 \%)$, and, as before, multiply the total by $3(14.1 \%$ x $3=42.3 \%)$. Finally, I determine the proportion of possible panels where there are no women. As with the all-female panel, there is only one permutation (MMM) to consider $(22 / 28 \times 21 / 27 \times 20 / 26=47.0 \%)$. Because these are all the possible permutations for three-judge panels, the proportions all add to $100 \%(0.6+10.1+42.3+47.0=100)$. In this hypothetical circuit, then, we see that $47 \%$ of panels constituted will be all male, and $53 \%$ of panels will have at least one woman serving on them.

Following Williams and Mean (2004), I create an interaction term between judge sex and the circuit composition measure, which allows me to investigate whether men and women are affected in the same way by the gender context of the circuit. This measure also lets us examine in what ranges the gender composition of the court matters. Given previous research showing that female judges are more likely to side with plaintiffs in discrimination cases, and that male judges are more likely to do so when seated on a panel with a female colleague, this might lead us to expect that all judges in a circuit will be more likely to cast pro-plaintiff votes as mixed-sex panels become more common. Alternatively, the "backlash" hypothesis suggests that men and women judges may respond differently to the effect of "exposure" to diversity, with men 
exhibiting a negative reaction (Kathlene 1994). These competing expectations will be evaluated for both civil rights cases broadly and employment discrimination cases in particular.

Dahlerup $(1988,2006)$ has argued that political scientists studying the effects of women's representation might do better to concentrate on "critical actors" within an institution instead of exclusively focusing on "critical mass." Consequently, I broaden the concept of the gender context of a court to include the sex of the circuit's chief judge. The chief judge presides over cases, leads court meetings, supervises court staff, oversees district and magistrate courts within the circuit, deals with judicial discipline, and represents the circuit in the Judicial Conference of the United States and to the other branches of government (Wasby 2003, 68). In order to become a chief judge, one must be the most senior judge in regular active service and younger than 65years-old (Hettinger, Lindquist, and Martinek 2003, 93). Having a female chief judge may create a climate in which both men and women judges are more apt to take civil rights claims more seriously and side with plaintiffs more frequently. Admittedly, this measure is an imperfect proxy for the presence of critical actors, since the "critical actor" concept is not necessarily limited to leaders within an organization, or to women. However, due to the lack of reliable information about specific judges and the ways in which they conduct themselves in their circuits, this operationalization represents the most consistent and replicable way to measure the concept.

To test the hypothesis that female leadership is associated with pro-plaintiff voting by both men and women, I included a dummy variable to account for the gender of the chief judge of the circuit. Four circuits had a woman serving as chief judge at any time between 1982 and 2002, and all of these women were Caucasian (Hettinger, Lindquist, and Martinek 2003, 95-97). 


\section{Control Variables}

To control for alternative explanations, I include variables related to the judge, panel, case, and circuit characteristics. Controls for a judge's gender (female $=1$ ) and race (non-white $=1$ ) were added to the model. Because a judge's general ideological predilection is likely to color the lens through which she evaluates civil rights disputes, I include the Giles, Hettinger, and Peppers (2001) measure of individual ideology that ranges from -1 (most liberal) to +1 (most conservative). Using the Poole (1998) common space NOMINATE scores, a judge is assigned the ideology score for the appointing president if there is no home-state senator of the president's party, and the ideology score for the home-state senator if senatorial courtesy is present. As a continuous measure of ideology, it is superior to a dichotomous approach (i.e., using the party of the appointing president) because it is both more precise and because it allows distinctions to be made between ideological extremes and moderates. Moreover, it offers the advantage of face, convergent, and construct validity and outperforms other commonly used measures (Epstein et al. 2007, 4-5).

In addition to factors relating to personal characteristics of the judges, I also control for factors related to both the panel and the case. To account for the gender context of the panel, I include a variable for the number of women actually sitting on the panel in a given case. I expect that, consistent with previous work, male judges on mixed sex panels will be more likely to side with plaintiffs, and I evaluate this expectation using both a broad sample of civil rights cases as well as a sample of employment discrimination cases.

Judicial scholars have documented the emphasis on consensus throughout the Courts of Appeals (Hettinger, Lindquist, and Martinek 2006; Howard 1981), as both an institutional norm as well as a coping mechanism in dealing with high workload. Since in the Courts of Appeals, 
cases are decided by majority vote in three-judge panels, I include a measure of the median ideology on the panel (Giles, Hettinger, and Peppers 2001). Another important control variable has to do with the tendency of appellate panels to uphold the decisions of district court judges. Examining data from the Administrative Office of the Courts, political scientists have found that reversal rates range from 9 percent for all cases heard on the merits to about 30 percent for published cases (Hettinger, Lindquist, and Martinek 2006; Songer, Sheehan, and Haire 2000). To control for this tendency to affirm, I include a variable to account for the ideological direction of the lower court's decision. I also include a dummy variable that is equal to 1 if the US government is a party in the case and advocating the conservative position, 0 if not participating, and -1 if a party and advocating the liberal position in order to control for its high win rate in the Courts of Appeals (Songer, Sheehan, and Haire 1999). ${ }^{5}$

Finally, I control for several circuit-level characteristics that could affect the likelihood of a pro-plaintiff vote. There is substantial variation across courts in terms of institutional practices and norms (Howard 1981; Lindquist 2007), so dummy variables for each circuit are included. Variables for the race of the chief judge ( $1=$ non-white), and the racial make-up of the circuit (calculated in the same way as the gender composition variable) were added to control for the possibility that racial diversity or minority leadership within the circuit affect outcomes for plaintiffs in civil rights cases. Because the decisions of individual panels must reflect circuit precedent, I control for the relative liberalism or conservatism of each circuit by using the Giles, Hettinger, and Peppers (2001) scores to calculate the median ideological value for each circuit in each year (Lindquist, Haire, and Songer 2007). 


\section{Data and Methods}

The data for this project were drawn from two different databases of decisions from the US Courts of Appeals. First, the broad civil rights sample is from the Multi-User Database on the US Courts of Appeals (Kuersten and Haire 2007; Songer 1997), including only appeals decided by three-judge panels from the 11, numbered circuits for a 20-year period (1982-2002), ending at the last year coded in the database. ${ }^{6}$ Decisions by en banc panels are excluded in order to maximize comparability across circuits. This is done for several reasons. First, the literature on juries suggests that group dynamics may vary with the size of the group (Saks and Marti 1997), making it problematic to combine groups of three with larger-sized groups for comparison. Second, because en bancs require that all active judges within a circuit sit to rehear a case, the specific number of judges in an en banc varies depending on the number of judges in each circuit each year. Moreover, the Ninth Circuit utilizes a different selection mechanism (random selection) for en banc panels than any other circuit, pursuant to the 1978 Omnibus Judge Act. Finally, given the relative rarity that circuits hear cases en banc, the most common group decision-making environment for judges is the three-judge panel. ${ }^{7}$ For these reasons, comparing decisions by three-judge panels across all circuits should yield more generalizable findings.

The years for the analysis were selected to maximize comparability across circuits (i.e., addressing the creation of the Eleventh Circuit in 1981) and to ensure ample numbers of women judges for analysis. Cases coded as civil rights in this sample included prisoner civil rights claims; race discrimination; sex discrimination; discrimination based on disability, age, religion, nationality, or sexual orientation; voting rights claims; desegregation claims; and alien petitions. 
Because the Multi-User Database consists of a probability sample of 30 published cases per circuit-year, there were insufficient employment discrimination cases represented across all circuits to conduct a meaningful analysis of the subset of sex discrimination cases. For this reason, I supplemented the civil rights sample (from the Multi-User Database) with a sample of published sex discrimination cases with female plaintiffs from Sunstein et al. (2006), which span from 1995 to 2002. Demographic information about judges on panels was obtained from the Gryski and Zuk (2006) judge attributes dataset and the Federal Judicial Center. Because the dependent variable is a dichotomous measure, ordinary least squares regression is inappropriate and logistic regression is employed (Long 1997). To address the non-independence of votes within a case, I estimate the model using robust standard errors clustered on the case and include controls for time.

$<$ Figure 1 about here>

\begin{abstract}
ANALYSIS
Figure 1 shows the changes in the frequency of mixed-sex panels for each circuit over a 20-year period (1982-2002). A few circuits (e.g., the Third and the Ninth) remained consistently high in terms of the numbers of possible mixed-sex panels constituted, while the Tenth Circuit's numbers declined over this time period. But overall, most circuits experienced a boost in the proportion of possible mixed-sex panels in the mid-1990s, reflecting the success of President Clinton's strategy to diversify the bench (Segal 2000). In terms of judge ideology, female judges in both the civil rights and sex discrimination samples were, as a whole, more liberal than the male judges. However, men and women cast about the same proportion of liberal votes in civil rights cases (34\% for men and $35 \%$ by women). In sex discrimination cases, women cast liberal votes $44 \%$ of the time, while men did so $34 \%$ of the time.
\end{abstract}


<Table 1 about here>

To evaluate expectations related to the gender context of each circuit, Table 1 displays the results for both the civil rights sample and the sex discrimination sample. The civil rights sample is further divided into two time periods (1982-1994 and 1995-2002) to provide comparability with the sex discrimination sample (which only includes the years 1995-2002). Because the coefficients and statistical significance for interaction terms in logit models are not directly interpretable, the marginal effects and standard errors were calculated for substantively meaningful values to provide a more accurate interpretation of how circuit and panel characteristics condition the behavior of individual judges (Brambor, Golder, and Clark 2006). Diagnostics revealed no problematic levels of collinearity (e.g., greater than 0.9) between judge gender and the presence of a woman on a panel, judge gender and circuit gender composition, or circuit gender composition and the presence of a woman on a panel.

$<$ Figure 2 about here>

First, we examine the interaction between judge gender and the gender composition of the circuit in all civil rights cases (1982-2002). Figure 2 illustrates that, when all other variables are held at their median or mean values, there is a statistically significant, positive effect of circuit composition on both men and women's voting in civil rights cases. However, the magnitude of the effect is much larger for women. Looking at the predicted probabilities for women alone, the likelihood of a pro-plaintiff vote increases from $9.6 \%$ to $40.2 \%$ as the frequency of mixed-sex panels ranges from $15 \%$ to $60 \%$. For male judges alone, the predicted probability increases only about one percentage point over the same range (from 21.9 to 23.0). These findings support the expectation that greater exposure to female judges within a court will 
be related to greater support for civil rights claims overall, but with the caveat that this factor has a larger impact on individual women judges than on men.

In contrast to the civil rights sample, in the sex discrimination cases, the marginal effects (not shown) indicate no statistically significant relationship between circuit composition and judge gender. This finding appears counter-intuitive, since sex discrimination cases should arguably make the gender context of a court more salient for judges, as compared to a broad array of civil rights cases. One likely explanation for this result has to do with the years for each analysis and the relative presence of women judges during those times. To explore this possibility, Table 1 also displays the results for all civil rights cases, separated into two time periods for comparability with the sex discrimination sample: 1982-1994 and 1995-2002. When analyzed in this fashion, the marginal effects reveal that it was the earlier time period (19821994) driving the civil rights results in column 1, since the conditional relationship is not significant in the latter time period. Between 1982 and 1994, the proportion of mixed-sex panels in a circuit ranged from zero to 0.51 with a median value of 0.21 ; in comparison, between 1995 and 2002, this variable ranged from 0.15 to 0.65 with a median value of 0.36 .

Linking back to the critical mass literature, Kanter (1977, 966-967) made a distinction between "skewed" organizations, in which women might make up $15 \%$ or less of the group, and "tilted" organizations, in which women comprised 15-40\% of the group and could begin to influence the culture of the organization. Kanter (1977) hypothesized that in "skewed" organizations in which women were only "tokens," they might act in ways that would minimize their difference. Indeed, Kanter's (1977) work has been read to "require" larger proportions of women in order to affect change. However, Bratton (2005) observed that women in "skewed" state legislatures were still able to effectively represent women's interests, despite their "token" 
status. The results here are consistent with Bratton's (2005) finding, in that a relatively small number of women can make a difference in institutional outcomes.

The critical actor hypothesis posits that the presence of a female chief judge will increase the propensity of men and women judges to support plaintiffs claiming discrimination. We find mixed support for this proposition. In two of the three civil rights models, the gender of the chief judge is not related to pro-plaintiff votes, either by itself, or as conditioned on judge gender. Although there is a significant conditional relationship in civil rights cases during the 1982-1994 period, this is not very substantively meaningful, as only one woman served as chief judge during this period (Doris Sloviter from the 11th Circuit). However, in sex discrimination cases with female plaintiffs (1995-2002), a female chief judge was weakly associated $(\mathrm{p} \leq 0.10)$ with a higher likelihood of a pro-plaintiff vote. When interacted with the gender of the judge, the marginal effects reveal that men and women judges are not affected differently by the sex of the chief judge during this time period. Even controlling for ideology, male and female judges in circuits with women chief judges were more likely to support female plaintiffs in sex discrimination cases.

Supporting the findings of previous studies, the marginal effects show that in the sex discrimination cases, as the number of women judges on a panel increases, both men and women judges are significantly more likely to side with a female plaintiff. As the number of women increases from one to two, the predicted probability of a male judge casting a pro-plaintiff vote increases from about 0.45 to about 0.65 ; the predicted probability for women increases from 0.80 to almost 0.90 (as the number of women on a panel increases from one to three). However, in civil rights cases, female judges do not have a "liberalizing" effect on their male colleagues. All else equal, as a panel becomes diversified with respect to sex, the probability of a male judge 
casting a liberal vote actually decreases, dropping moderately from about $27 \%$ (when there are no women) to $21 \%$ (when there is one woman) to $16 \%$ (when there are two women). There is, however, a 20-point increase in the probability of a pro-plaintiff vote by a female judge when a second woman is present on a panel (from $17 \%$ to $37 \%$ ), and an additional 25 -point increase (to $62 \%)$ when a panel is entirely comprised of women. These results are consistent with the interpretation that sex discrimination appeals are distinctive in producing more favorable outcomes for female plaintiffs, and are not part of a larger phenomenon in civil rights cases more generally. It is also consistent with sociological research on small groups that finds men in small groups to be more likely to defer to women when a task is feminine-typed, compared to masculine- and neutral-typed tasks (Correll and Ridgeway 2003, 38; Ridgeway 2001; Ridgeway and Smith-Lovin 1999). Alternatively, men's voting in civil rights cases may signal a type of "backlash" behavior akin to what Kathlene (1994) observed in her study of state legislators, though these data do not allow us to gauge the tone of male judges' deliberations.

With respect to race, minority chief judges are positively related to pro-plaintiff votes in the 1995-2002 period for civil rights cases. This period includes two minority chief judges (there was only one minority chief judge in the earlier period), providing us with further evidence that under certain conditions, non-traditional chief judges are associated with more liberal decisions within a circuit. As with the results for chief judge gender, we should be cautious about attributing causality, both because of the small number of minority men and because circuits that select non-traditional chief judges may generally be more likely to side with plaintiffs.

The other control variables behave largely as expected. Ideological preferences of the judge and the panel were consistently significant predictors of pro-plaintiff votes, as was the ideological direction of the lower court's decision. In the civil rights models, minority judges 
were no more likely to cast pro-plaintiff votes than white judges, as in previous research on the federal courts (Walker and Barrow 1985; Segal 2000). However, in sex discrimination cases, the coefficient for non-white judges was positive and weakly significant (at $\mathrm{p} \leq .10$ ), showing that these judges were somewhat more likely to support plaintiffs claiming sex discrimination.

\section{Discussion}

This article examines the concept of a critical mass broadly to encompass the range of behavioral changes observed in both men and women when the political institution they inhabit is diversified (Childs and Krook 2006, 524). Underscoring the fruitfulness of this approach, the results show that increasing the diversity of the bench does matter for legal outcomes even when women are not in the majority. And while some of the results suggest support for a "substantive representation" interpretation, the effects go beyond women judges representing "women's interests" by their votes in sex discrimination cases. Specifically, I find evidence that court diversity increases the propensity of both men and women judges to support both male and female plaintiffs in a broad array of civil rights cases. Likewise, in sex discrimination cases, the presence of a female chief judge in the circuit was related to a higher likelihood of support for female plaintiffs by both men and women judges. These two findings point to a change in the organizational culture of a court as a result of diversification. ${ }^{8}$

That being said, the effect of a court's composition in civil rights cases was substantially more pronounced for female judges than for their male colleagues. Moreover, the court's composition does not emerge as a significant predictor in the 1995-2002 time period, suggesting that either the types of cases or the larger societal context related to diversity in the 1980s and early 1990s may be contributing factors. Future research should explore whether this limited effect was due to the non-traditional judges themselves (perhaps acting as "tokens" in their 
attitudes or behaviors). For instance, one study of "skewed" state legislatures concluded that "women in very homogeneous settings do not react to their token status by minimizing gender differences in agenda setting” (Bratton 2005, 121). As attitudes about gender evolve over time and new judges assume the place of older judges on the bench, researchers should continue to revisit the question of whether court diversity affects legal outcomes.

Additionally, studies on gender and small group decision-making processes (e.g., Ridgeway 1981, 2002) present promising avenues for further theoretical development about the diversification of the judiciary. In lieu of the opportunity to observe judges' deliberations, this kind of research can help judicial scholars better theorize about how panel dynamics in different types of cases are affected by the gender makeup of the group. For example, male judges on mixed-sex panels may be more likely to join female colleagues in supporting female plaintiffs in sex discrimination cases because such cases are viewed as "feminine" typed, leading male judges to defer to the women on the panel. En banc panels might also be a fruitful area of inquiry for scholars interested in how gender affects the dynamics of larger groups, especially given the heightened salience of cases that are reheard en banc. Finally, the findings highlight the advantages of seeking out theoretically-based, institutionally-appropriate measures of the composition of an institution and examining their effects on both men and women

\section{REFERENCES}

Allen, David W. and Diane E. Wall. 1993. "Role Orientations and Women State Supreme Court Justices." Judicature 77: 156-65. 
Aries, Elizabeth. 1998. "Gender differences in interaction: A reexamination.” In Sex Differences and Similarities in Communication. eds. D. J. Canary and K. Dindia. Mahwah, NJ: Erlbaum, 65-81.

Bazelon, Emily. "The Place of Women on the Court," The New York Times Magazine, 12 July, 2007.

Beckwith, Karen. 2007. "Numbers and Newness: The Descriptive and Substantive Representation of Women.” Canadian Journal of Political Science 40(1): 27-49.

Benesh, Sara C. 2006. “The Contribution of 'Extra' Judges.” University of Arizona Law Review 48: 301-315.

Boyd, Christina, L., Lee Epstein, and Andrew D. Martin. 2010. "Untangling the Casual Effects of Sex on Judging." American Journal of Political Science 54(2): 389-411.

Brambor, Thomas, William Roberts Clark, and Matt Golder. 2006. "Understanding Interaction Models: Improving Empirical Analyses." Political Analysis 14(1): 63-82.

Bratton, Kathleen A. 2005. "Critical Mass Theory Revisited: The Behavior and Success of Token Women in State Legislatures.” Politics and Gender 1(1): 97-125.

Chatman, Jennifer A. and Sandra E. Spataro. 2005. "Using Self-Categorization Theory to Understand Relational Demography-Based Variations in People's Responsiveness to Organizational Culture.” Academy of Management Journal 48(2): 321-331.

Childs, Sarah and Mona Lena Krook. 2006. "Should Feminists Give Up on Critical Mass? A Contingent Yes.” Politics \& Gender 2(4): 522-530.

Childs, Sarah and Mona Lena Krook. 2008. “Critical Mass Theory and Women's Political Representation." Political Studies 1-12. 
Coates, Jennifer. 1988. “Gossip Revisited: Language in All-Female Groups.” In Women in Their Speech Communities, eds. Jennifer Coates and Deborah Cameron. London: Longman.

Cohen, Jonathan Matthew. 2002. Inside the Appellate Courts: The Impact of Court Organization on Judicial Decision Making in the United States Courts of Appeals. Ann Arbor: University of Michigan Press.

Collins, Todd A. and Laura Moyer. 2008. "Gender, Race, and Intersectionality on the Federal Appellate Bench.” Political Research Quarterly 61(2): 219-227.

Correll, Shelley J. and Cecilia L. Ridgeway. 2003. "Expectation States Theory.” Handbook of Social Psychology. ed., John Delamater. New York: Klewater Academic Plenum Publishers, 29-51.

Crowe, Nancy. 1999. The Effect of Judges' Sex and Race on Judicial Decision Making on the U.S. Court of Appeals, 1981-1996. Ph.D. Dissertation. Chicago: University of Chicago. Curran, Barbara A. and Clara N. Carson. 1994. The Lawyer Statistical Report: the US Legal Profession in the 1990s. Chicago: American Bar Foundation.

Dahlerup, Drude. 1988. "From a Small to a Large Minority: Women in Scandinavian Politics," Scandinavian Political Studies 11(4): 275-97.

Dahlerup, Drude. 2006. "The Story of the Theory of 'Critical Mass."” Politics and Gender 2(4): 511-22.

Davis, Sue. 1993. “The Voice of Sandra Day O'Connor.” Judicature 77: 134-39.

Duerst-Lahti, Georgia and Rita-Mae Kelly. 1995. Gender Power, Leadership, and Governance. Ann Arbor: University of Michigan Press.

Eagly, Alice H. and Blair T. Johnson. 1990. "Gender and Leadership Style: A Meta-Analysis." Psychological Bulletin 108: 233-256. 
Epstein, Cynthia Fuchs, Robert Saute, Bonnie Oglensky, and Martha Gever. 1995. “Glass Ceilings and Open Doors: Women's Advancement in the Legal Profession: A Report to the 'Committee on Women in the Profession,' the Association of the Bar of the City of New York." Fordham Law Review 64 (November): 192-378.

Epstein, Lee, Andrew D. Martin, Jeffrey A. Segal, and Chad Westerland. 2007. "The Judicial Common Space." Journal of Law, Economics, and Organization 23(2): 303-325.

Farhang, Sean and Gregory Wawro. 2004. "Institutional Dynamics on the U.S. Court of Appeals: Minority Representation Under Panel Decision Making." Journal of Law, Economics and Organization 20: 299-330.

Federal Judicial Center. no date. "Federal Judges Biographical Database." $<$ http://www.fjc.gov/public/home.nsf/hisj>.

Giles, Michael W., Virginia Hettinger, and Todd Peppers. 2001. "Picking Federal Judges: A Note on Policy and Partisan Selection Agendas." Political Research Quarterly 54: 623641.

Gilligan, Carol. 1982. In a Different Voice: Psychological Theory And Women's Development. Cambridge: Harvard University Press.

Grey, Sandra. 2002. "Does Size Matter? Critical Mass and New Zealand's Women MPs.” Parliamentary Affairs 55(1): 19-29.

Gryski, Gerald and Gary Zuk. 2006. Update to the Multi-User Database on the Attributes of United States Appeals Court Judges, 1801-2000.

Hettinger, Virginia A., Stefanie A. Lindquist, and Wendy L. Martinek. 2003. "The Role and Impact of Chief Judges in the United States Courts of Appeals." Justice System Journal 24: 91-117. 
Hettinger, Virginia A., Stefanie A. Lindquist, and Wendy L. Martinek. 2006. Judging on a Collegial Court: Influences on Federal Appellate Decision Making. Charlottesville: University of Virginia Press.

Howard, J. Woodford. 1981. Courts of Appeals in the Federal System. Princeton: Princeton University Press.

Kanter, Rosabeth Moss. 1977. "Some Effects of Proportions on Group Life: Skewed Sex Ratios and Responses to Token Women." American Journal of Sociology 82(5): 965-990.

Kathlene, Lyn. 1994. "Power and Influence in State Legislative Policymaking: The Interaction of Gender and Position in Committee Hearing Debates." American Political Science Review 88(3): 560-573.

Kuersten, Ashlyn and Susan B. Haire. 2007. Update to Multi-User Database on the United States Courts of Appeals, 1997-2002. Ann Arbor, Michigan: Inter-university Consortium for Political and Social Research.

Lindquist, Stefanie A. 2007. "Bureaucratization and Balkanization." University of Richmond Law Review 41(3): 659-706.

Lindquist, Stefanie A., Susan B. Haire, and Donald R. Songer. 2007. "Supreme Court Auditing of the U.S. Courts of Appeals: An Organizational Perspective." Journal of Public Administration Research and Theory 17: 607-624.

Long, J. Scott. 1997. Regression Models for Categorical and Limited Dependent Variables. Thousand Oaks, CA: Sage.

Martin, Elaine. 1999. "Women Judges: The New Generation" in Women in Politics: Outsiders or Insiders. ed. Lois Duke Whitaker. Upper Saddle River, NJ: Prentice Hall.

Martin, Elaine. 1990. "Men and Women on the Bench: Vive La Difference?” Judicature 73: 204. 
Martin, Elaine and Barry Pyle. 2005. "Women of the Courts Symposium: State High Courts and Divorce: the Impact of Judicial Gender.” University of Toledo Law Review 36: 923.

Martin, Patricia Yancey, John R. Reynolds, and Shelley Keith. 2002. "Gender Bias and Feminist Consciousness among Judges and Attorneys: A Standpoint Theory Analysis.” Signs 27: $665-701$.

McCall, Madhavi. 2008. “Structuring Gender’s Impact: Judicial Voting Across Criminal Justice Cases.” American Politics Research 36(2): 264-296.

Milliken, Frances J., and Luis L. Martins. 1996. "Searching for Common Threads: Understanding the Multiple Effects of Diversity in Organizational Groups.” Academy of Management Review 21(2): 402-433.

Peresie, Jennifer L. 2005. "Female Judges Matter: Gender and Collegial Decision-Making in the Federal Appellate Courts.” Yale Law Journal 114: 1759.

Poggione, Sarah. 2004. "Exploring Gender Differences in State Legislators' Policy Preferences." Political Research Quarterly 57(2): 305-314.

Poole, Keith T. 1998. "Estimating a Basic Space from a Set of Issue Scales.” American Journal of Political Science 42: 954-993.

Ridgeway, Cecilia. 1981. "Non-conformity, Competence, and Influence in Groups: A Test of Two Theories.” American Sociological Review 46: 333-347.

Ridgeway, Cecilia. 2001. "Gender, Status, and Leadership.” Journal of Social Issues 57(4): 637655. 
Ridgeway, Cecilia, and Lynn Smith-Lovin. 1999. "The Gender System and Interaction.” Annual Review of Sociology 25: 191-216.

Riordan, Christine M. 2000. "Relational Demography within Groups: Past Developments, Contradictions and New Directions." Research in Personnel and Human Resource Management 19: 131-173.

Saint-Germain, Michelle. 1989. "Does Their Difference Make A Difference? The Impact of Women on Public Policy in the Arizona Legislature.” Social Science Quarterly 70(4): 956-68.

Saks, Michael J. and Mollie Weighner Marti. 1997. "A Meta-Analysis of the Effects of Jury Size." Law and Human Behavior 21(5): 451-467.

Scherer, Nancy and Brett Curry. 2010. "Does Descriptive Race Representation Enhance Judicial Legitimacy? The Case of the U.S. Courts.” Journal of Politics 72(1): 90-104.

Segal, Jennifer A. 2000. "Representative Decision Making on the Federal Bench: Clinton's District Court Appointees." Political Research Quarterly 53(1): 137-150.

Smith-Lovin, Lynn, and Charles Brody. 1989. "Interruptions in Group Discussions: The Effects of Gender and Group Composition.” American Sociological Review 54: 424-35.

Solimine, Michael E. and Susan E. Wheatley. 1995. "Rethinking Feminist Judging.” Indiana Law Journal 70(3): 891-920.

Songer, Donald R. 1997. Multi-User Database on the U.S. Courts of Appeals, 1925-1996. Ann Arbor, Michigan: Inter-university Consortium for Political and Social Research.

Songer, Donald, R., Sue Davis, and Susan B. Haire. 1994. "A Reappraisal of Diversification in the Federal Courts: Gender Effects in the Courts of Appeals." Journal of Politics 56: 425 39. 
Songer, Donald R., Reginald Sheehan, and Susan B. Haire. 2000. Continuity and Change on the U.S. Courts of Appeals. Ann Arbor: University of Michigan Press.

Songer, Donald R., Reginald Sheehan, and Susan B. Haire. 1999. 'Do the 'Haves' Come Out Ahead Over Time?: Applying Galanter's Framework to the Decisions of the U.S. Courts of Appeals, 1925-1988." Law and Society Review 33(4): 811.

Sunstein, Cass, David Schkade, Lisa M. Ellman, and Andres Sawicki. 2006. Are Judges Political? An Empirical Analysis of the Federal Judiciary. Washington, DC: Brookings Institution.

Thomas, Sue. 1994. How Women Legislate. New York: Oxford University Press.

Tsui, Ann S., Terry D. Egan, and Charles A. O’Reilly. 1992. “Being Different: Relational Demography and Organizational Attachment.” Administratively Science Quarterly 37: 549-579.

Walker, Thomas and Deborah Barrow. 1985. "The Diversification of the Federal Bench: Policy and Process Ramifications.” Journal of Politics 47(2): 596-617.

Wasby, Stephen. 2003. “The Work of a Circuit’s Chief Judge.” Justice System Journal 24(1): 63-90.

Westergren, Sarah. 2004. "Gender Effects in the Courts of Appeals Revisited: The Data Since 1994." Georgetown Law Journal 92:689-708.

Wheelan, Susan A. and Anthony F. Verdi. 1992. "Differences in Male and Female Patterns of Communication in Groups: A Methodological Artifact?” Sex Roles 12: 993-1007. Williams, Helen M. and Lindsey J. Mean. 2004. "Measuring Gender Composition in Work Groups: A Comparison of Existing Methods." Organizational Research Methods 7: 45674. 
Yoon, Albert. 2005. "As You Like It: Senior Federal Judges and the Political Economy of Judicial Tenure.” Journal of Empirical Legal Studies 2(3): 495-549. 
Figure 1: Diversification of the Circuits, 1982-2002

Proportion of possible panels that are mixed sex in composition

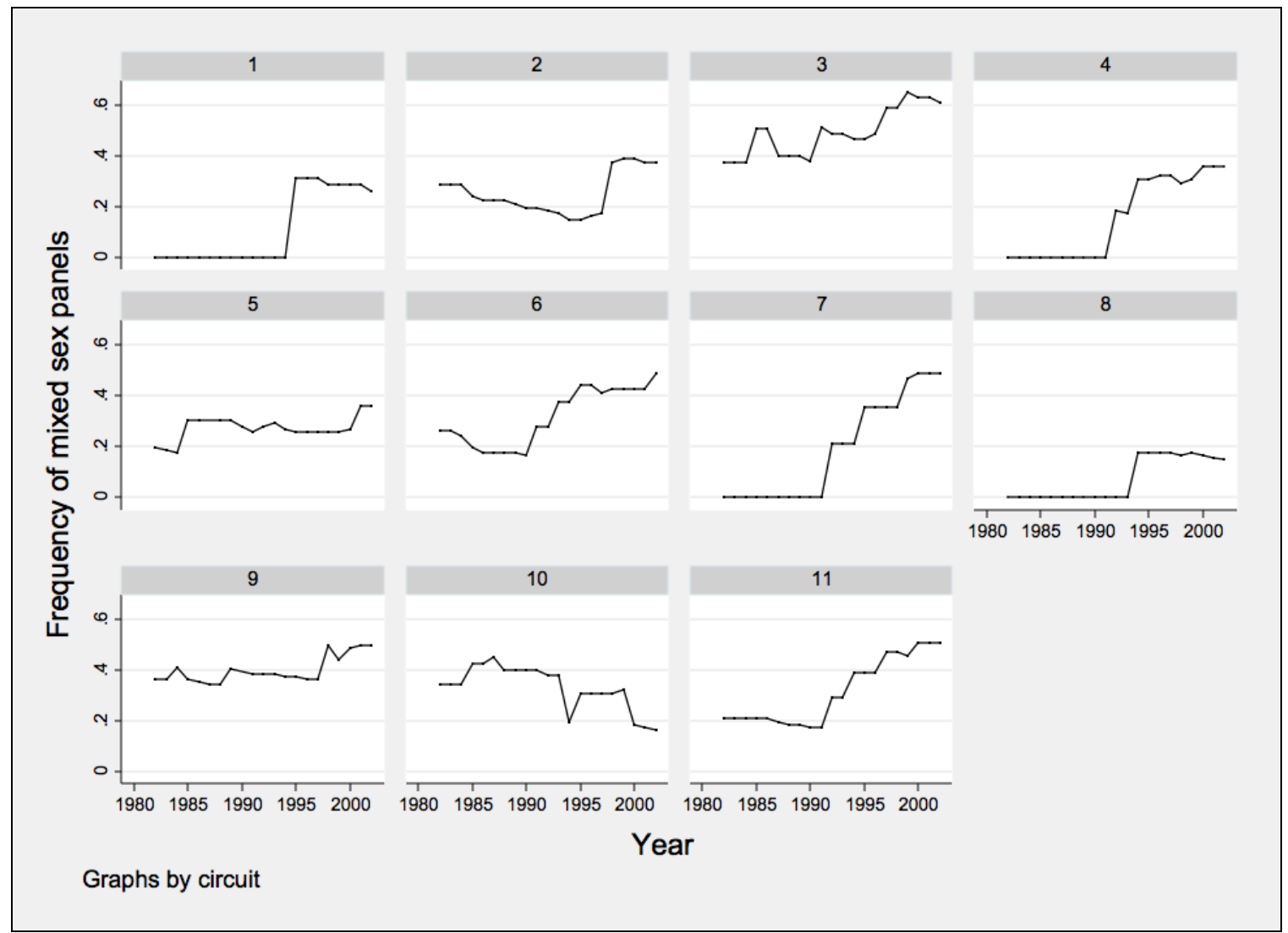

Source: Author's calculations 
Table 1: Logit Model of the Likelihood of a Pro-Plaintiff Vote

\begin{tabular}{|c|c|c|c|c|c|c|c|c|}
\hline & \multicolumn{2}{|c|}{$\begin{array}{l}\text { Civil Rights } \\
(\mathbf{1 9 8 2 - 2 0 0 2 )} \\
\end{array}$} & \multicolumn{2}{|c|}{$\begin{array}{c}\text { Sex Discrimination } \\
(\mathbf{1 9 9 5 - 2 0 0 2 )}\end{array}$} & \multicolumn{2}{|c|}{$\begin{array}{l}\text { Civil Rights } \\
(1982-1994)\end{array}$} & \multicolumn{2}{|c|}{$\begin{array}{l}\text { Civil Rights } \\
(\mathbf{1 9 9 5 - 2 0 0 2 )} \\
\end{array}$} \\
\hline & $\begin{array}{l}\text { Coef. } \\
\text { (RSE) }\end{array}$ & $\begin{array}{l}\text { Coef. } \\
\text { (RSE) }\end{array}$ & $\begin{array}{l}\text { Coef. } \\
\text { (RSE) }\end{array}$ & $\begin{array}{c}\text { Coef. } \\
\text { (RSE) }\end{array}$ & $\begin{array}{l}\text { Coef. } \\
(R S E)\end{array}$ & $\begin{array}{l}\text { Coef. } \\
\text { (RSE) }\end{array}$ & $\begin{array}{l}\text { Coef. } \\
\text { (RSE) }\end{array}$ & $\begin{array}{c}\text { Coef. } \\
\text { (RSE) }\end{array}$ \\
\hline Gender & $\begin{array}{l}-0.103 \\
(0.080)\end{array}$ & $\begin{array}{c}-2.88 * * * \\
(0.655)\end{array}$ & $\begin{array}{c}0.021 \\
(0.111)\end{array}$ & $\begin{array}{c}1.41 \\
(0.992)\end{array}$ & $\begin{array}{l}-0.034 \\
(0.119)\end{array}$ & $\begin{array}{c}-4.72 * * * \\
(1.12)\end{array}$ & $\begin{array}{l}-0.208 \\
(0.143)\end{array}$ & $\begin{array}{l}-2.37 * * \\
(0.961)\end{array}$ \\
\hline Minority & $\begin{array}{l}-0.107 \\
(0.121)\end{array}$ & $\begin{array}{c}-0.074 \\
(0.122)\end{array}$ & $\begin{array}{c}0.372 \\
(0.244)\end{array}$ & $\begin{array}{l}0.417^{*} \\
(0.251)\end{array}$ & $\begin{array}{l}-0.310^{*} \\
(0.167)\end{array}$ & $\begin{array}{l}-0.226 \\
(0.169)\end{array}$ & $\begin{array}{c}0.199 \\
(0.176)\end{array}$ & $\begin{array}{c}0.213 \\
(0.178)\end{array}$ \\
\hline Ideology & $\begin{array}{c}-0.507 * * * \\
(0.104)\end{array}$ & $\begin{array}{c}-.488 * * * \\
(0.106)\end{array}$ & $\begin{array}{c}-0.540 * * * \\
(0.178)\end{array}$ & $\begin{array}{c}-0.542 * * * \\
(0.182)\end{array}$ & $\begin{array}{c}-0.521 * * * \\
(0.132)\end{array}$ & $\begin{array}{c}-.500 * * * \\
(0.133)\end{array}$ & $\begin{array}{c}-0.621 * * * \\
(0.195)\end{array}$ & $\begin{array}{c}-0.639 * * * \\
(0.198)\end{array}$ \\
\hline $\begin{array}{r}\text { No. women on } \\
\text { panel }\end{array}$ & $\begin{array}{c}-0.188 \\
(0.160)\end{array}$ & $\begin{array}{c}-0.350 * * \\
(0.163)\end{array}$ & $\begin{array}{l}0.448^{*} \\
(0.233)\end{array}$ & $\begin{array}{c}0.592 * * \\
(0.247)\end{array}$ & $\begin{array}{l}-0.242 \\
(0.229)\end{array}$ & $\begin{array}{l}-0.400^{*} \\
(0.233)\end{array}$ & $\begin{array}{l}-0.122 \\
(0.259)\end{array}$ & $\begin{array}{l}-0.302 \\
(0.268)\end{array}$ \\
\hline $\begin{array}{l}\text { Judge gender* no. } \\
\text { women on panel }\end{array}$ & -- & $\begin{array}{l}1.34 * * * \\
(0.404)\end{array}$ & -- & $\begin{array}{l}-1.48 * * \\
(0.730)\end{array}$ & -- & $\begin{array}{l}1.84 * * \\
(0.719)\end{array}$ & -- & $\begin{array}{c}0.939 \\
(0.595)\end{array}$ \\
\hline Panel preferences & $\begin{array}{l}-0.511^{*} \\
(0.285)\end{array}$ & $\begin{array}{l}-0.564 * \\
(0.289)\end{array}$ & $\begin{array}{c}-1.54 * * * \\
(0.500)\end{array}$ & $\begin{array}{c}-1.42 * * * \\
(0.500)\end{array}$ & $\begin{array}{c}-0.834 * * \\
(0.404)\end{array}$ & $\begin{array}{c}-0.886^{* * *} \\
(0.413)\end{array}$ & $\begin{array}{l}-0.765 \\
(0.506)\end{array}$ & $\begin{array}{l}-0.862 * \\
(0.520)\end{array}$ \\
\hline US government & $\begin{array}{c}0.110 \\
(0.473)\end{array}$ & $\begin{array}{c}0.092 \\
(0.466)\end{array}$ & -- & -- & $\begin{array}{l}-0.406 \\
(0.497)\end{array}$ & $\begin{array}{l}0.390 \\
(0.492)\end{array}$ & $\begin{array}{l}2.02 * * \\
(0.816)\end{array}$ & $\begin{array}{l}1.99 * * \\
(0.796)\end{array}$ \\
\hline $\begin{array}{r}\text { Direction of lower } \\
\text { court }\end{array}$ & $\begin{array}{l}5.01 * * * * \\
(0.490)\end{array}$ & $\begin{array}{l}5.00^{* * * *} \\
(0.487)\end{array}$ & $\begin{array}{c}1.34 * * * \\
(0.300)\end{array}$ & $\begin{array}{l}1.33 * * * \\
(0.303)\end{array}$ & $\begin{array}{l}5.01 * * * \\
(0.709)\end{array}$ & $\begin{array}{l}4.99 * * * \\
(0.706)\end{array}$ & $\begin{array}{l}5.83^{* * * *} \\
(0.894)\end{array}$ & $\begin{array}{l}5.79 * * * \\
(0.859)\end{array}$ \\
\hline $\begin{array}{r}\text { Circuit gender } \\
\text { composition }\end{array}$ & $\begin{array}{c}0.307 \\
(0.848)\end{array}$ & $\begin{array}{c}0.188 \\
(0.861)\end{array}$ & $\begin{array}{l}0.504 \\
(3.09)\end{array}$ & $\begin{array}{l}0.738 \\
(3.08)\end{array}$ & $\begin{array}{l}-2.18 \\
(1.78)\end{array}$ & $\begin{array}{l}-3.05 \\
(1.86)\end{array}$ & $\begin{array}{c}1.67 \\
(3.25)\end{array}$ & $\begin{array}{c}1.27 \\
(3.29)\end{array}$ \\
\hline $\begin{array}{r}\text { Judge } \\
\text { gender*circuit } \\
\text { gender composition }\end{array}$ & -- & $\begin{array}{c}3.47 * * * \\
(1.30)\end{array}$ & -- & $\begin{array}{l}0.351 \\
(2.01)\end{array}$ & -- & $\begin{array}{l}8.55 * * * \\
(2.57)\end{array}$ & -- & $\begin{array}{c}2.20 \\
(1.75)\end{array}$ \\
\hline Chief judge gender & $\begin{array}{l}-0.318 \\
(0.296)\end{array}$ & $\begin{array}{l}-0.435 \\
(0.310)\end{array}$ & $\begin{array}{c}1.07 * \\
(0.617)\end{array}$ & $\begin{array}{c}0.914 \\
(0.617)\end{array}$ & $\begin{array}{l}-0.415 \\
(0.639)\end{array}$ & $\begin{array}{l}-0.339 \\
(0.677)\end{array}$ & $\begin{array}{c}0.262 \\
(0.516)\end{array}$ & $\begin{array}{l}0.024 \\
(0.544)\end{array}$ \\
\hline $\begin{array}{l}\text { Judge gender*chief } \\
\text { judge gender }\end{array}$ & -- & $\begin{array}{c}0.026 \\
(0.368)\end{array}$ & -- & $\begin{array}{c}0.685 \\
(0.434)\end{array}$ & -- & $\begin{array}{l}-1.58 * * \\
(0.805)\end{array}$ & -- & $\begin{array}{c}0.791 \\
(0.495)\end{array}$ \\
\hline Chief judge race & $\begin{array}{l}-0.101 \\
(0.411)\end{array}$ & $\begin{array}{l}-0.019 \\
(0.406)\end{array}$ & $\begin{array}{l}-0.370 \\
(0.844)\end{array}$ & $\begin{array}{l}-0.415 \\
(0.841)\end{array}$ & $\begin{array}{c}0.157 \\
(0.841)\end{array}$ & $\begin{array}{c}0.255 \\
(0.858)\end{array}$ & $\begin{array}{c}1.48^{*} \\
(0.884)\end{array}$ & $\begin{array}{l}1.48^{*} \\
(0.872)\end{array}$ \\
\hline $\begin{array}{r}\text { Circuit racial } \\
\text { composition }\end{array}$ & $\begin{array}{c}0.766 \\
(0.928)\end{array}$ & $\begin{array}{c}0.787 \\
(0.929)\end{array}$ & $\begin{array}{l}-1.45 \\
(3.18)\end{array}$ & $\begin{array}{l}-1.47 \\
(3.19)\end{array}$ & $\begin{array}{l}2.51^{*} \\
(1.48)\end{array}$ & $\begin{array}{l}2.56^{*} \\
(1.51)\end{array}$ & $\begin{array}{c}2.62 \\
(0.478)\end{array}$ & $\begin{array}{c}2.38 \\
(3.75)\end{array}$ \\
\hline Circuit preferences & $\begin{array}{l}-0.020 \\
(0.240)\end{array}$ & $\begin{array}{l}-0.020 \\
(0.243)\end{array}$ & $\begin{array}{l}-0.302 \\
(0.791)\end{array}$ & $\begin{array}{l}-0.298 \\
(0.790)\end{array}$ & $\begin{array}{c}0.126 \\
(0.498)\end{array}$ & $\begin{array}{c}0.183 \\
(0.499)\end{array}$ & $\begin{array}{l}-0.298 \\
(0.835)\end{array}$ & $\begin{array}{l}-0.287 \\
(0.839)\end{array}$ \\
\hline Constant & $\begin{array}{l}-1.36 * * \\
(0.552)\end{array}$ & $\begin{array}{l}-1.35^{* *} \\
(0.552)\end{array}$ & $\begin{array}{l}0.016 \\
(1.32)\end{array}$ & $\begin{array}{l}-0.065 \\
(1.33)\end{array}$ & $\begin{array}{l}-2.58 * * \\
(1.04)\end{array}$ & $\begin{array}{l}-2.66 * * \\
(1.05)\end{array}$ & $\begin{array}{c}-4.09 * * * \\
(1.43)\end{array}$ & $\begin{array}{l}-3.73 * * \\
(1.44)\end{array}$ \\
\hline $\begin{array}{c}N \\
\end{array}$ & $\begin{array}{l}2,664 \\
0,1722\end{array}$ & $\begin{array}{c}2,664 \\
0,1803\end{array}$ & $\begin{array}{c}870 \\
01502\end{array}$ & $\begin{array}{c}870 \\
01560\end{array}$ & $\begin{array}{l}1,511 \\
0.1605\end{array}$ & $\begin{array}{l}1,511 \\
0,1726\end{array}$ & $\begin{array}{c}1,153 \\
0,3030\end{array}$ & $\begin{array}{c}1,153 \\
03103\end{array}$ \\
\hline $\begin{array}{l}\text { Pseudo R } \\
\text { Model sig. }\end{array}$ & $\mathrm{p} \leq .001$ & $\mathrm{p} \leq .001$ & $\mathrm{p} \leq .001$ & $\mathrm{p} \leq .001$ & $\mathrm{p} \leq .001$ & $\mathrm{p} \leq .001$ & $\mathrm{p} \leq .001$ & $\mathrm{p} \leq .001$ \\
\hline
\end{tabular}

Notes: *** significant at $\mathrm{p} \leq 0.01$ (two-tailed). $* *$ significant at $\mathrm{p} \leq 0.05$ (two-tailed). *significant at $\mathrm{p} \leq 0.10$ (two-tailed). Output for dummy variables for years and circuits omitted because of space limitations. 
Figure 2: Effect of Court's Composition on Men and Women Judges

(Civil Rights Cases, 1982-2002)

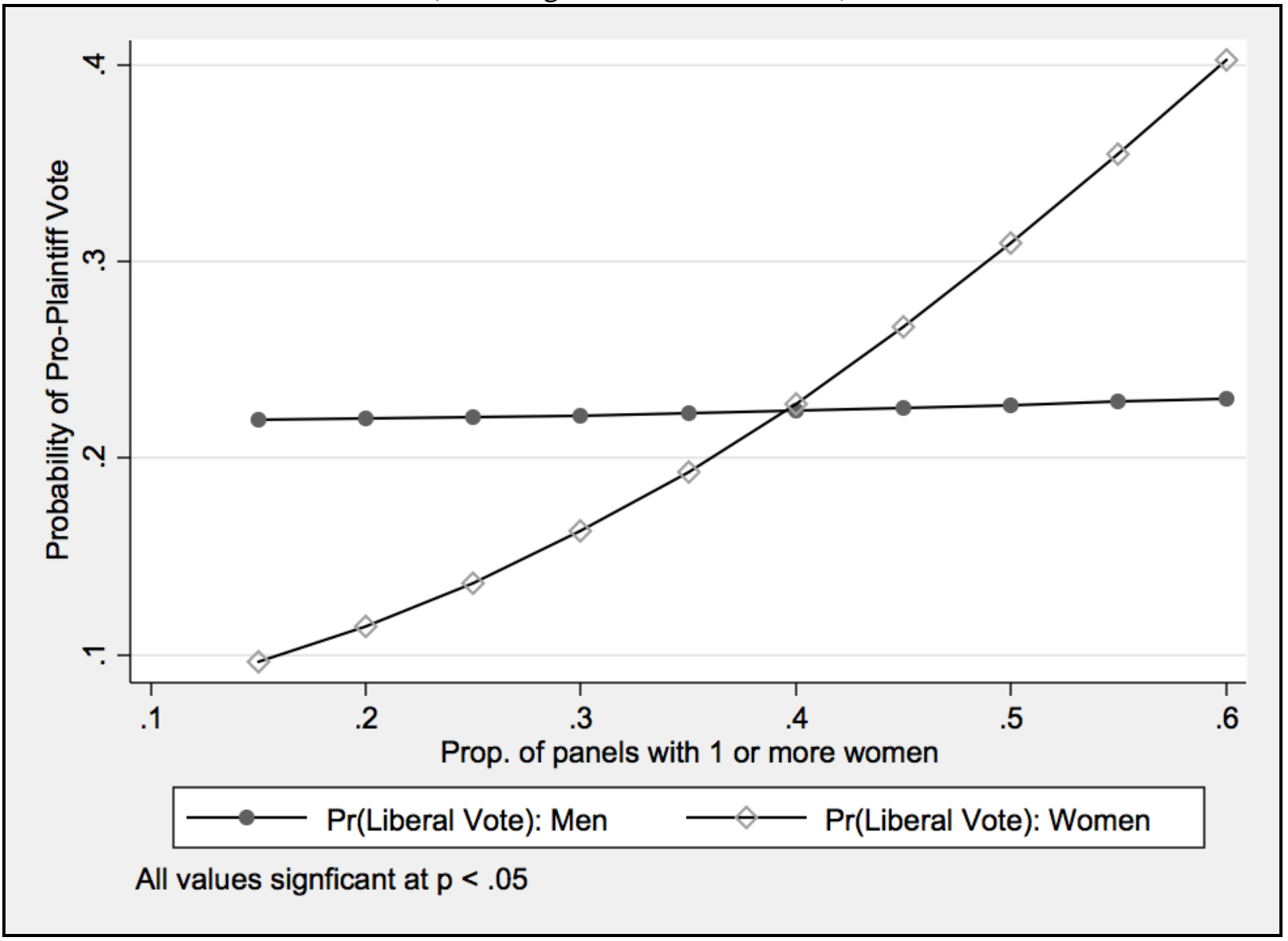




\section{ENDNOTES}

${ }^{1}$ The finding in criminal cases was limited to female judges of color, not all female judges.

${ }^{2}$ I do not mean to imply that there is a single female experience that transcends race, class, or other social categories. Rather, my point is that women in the federal judiciary have been professionally socialized in similar environments and that those experiences are likely to shape their worldview and perhaps their interpretation of the law (Bazelon 2007).

${ }^{3}$ Scherer and Curry (2010) find that increasing racial diversity on the federal courts may promote "backlash" among whites in the mass public.

${ }^{4}$ The results for the analysis do not substantively change when only active judges are included.

${ }^{5}$ Unfortunately, the sample of sex discrimination cases used for this analysis from Sunstein et al. (2006) does not include an indicator for the participation of the federal government as a party, so this control is omitted from the sex discrimination analysis. However, inspection of the data reveals only 18 observations (6 cases) out of 870 where the US government was named as a party, so this exclusion is unlikely to be affecting the results.

${ }^{6}$ The DC Circuit is excluded because of missing data.

${ }^{7}$ The median annual number of en banc decisions for a given circuit during the period of this study was 6. 
${ }^{8}$ All of the analyses control for ideology, which means that the results for gender hold independent of ideology. However, recent research that has used alternative methodological specifications to deal with this specific concern has also come to similar conclusions. Boyd, Epstein, and Martin (2010) use propensity score matching to account for "unbalanced" samples (in which female judges are more liberal than male judges on average) and find that gender has an independent effect from ideology in sex discrimination cases. 